\title{
The Eco-City: Ten Key Transport and Planning Dimensions for Sustainable City Development
}

\author{
by \\ Jeffrey R. Kenworthy \\ Associate Professor in Sustainable Settlements \\ Institute for Sustainability and Technology Policy \\ Murdoch University \\ Perth, Western Australia, 6150
}

BIOGRAPHY

Jeffrey Kenworthy is Associate Professor in Sustainable Settlements in the Institute for Sustainability and Technology Policy at Murdoch University in Perth. He is best known for his international comparisons of cities around the theme of automobile dependence. He has published extensively in the transport and planning fields for 26 years and is co-author with Peter Newman of Sustainability and Cities: Overcoming Automobile Dependence (1999) and The Millennium Cities Database for Sustainable Transport (2001) with Felix Laube.

\begin{abstract}
Making existing cities and new urban development more ecologically based and livable is an urgent priority in the global push for sustainability. This paper discusses ten critical responses to this issue and summarises them in a simple conceptual model that places the nexus between transport and urban form at the heart of developing an eco-city. This involves compact, mixed use urban form, well defined higher density, human-oriented centres, priority to the development of superior public transport systems and conditions for non-motorised modes, with minimal road capacity increases, and protection of the city's natural areas and food producing capacity. These factors form the framework in which everything else is embedded and must operate and without addressing them only marginal changes in urban sustainability can be made. Within this framework environmental technologies need to be extensively applied. Economic growth needs to emphasise creativity and innovation and to strengthen the environmental, social and cultural amenities of the city. The public realm throughout the city needs to be of a high quality and sustainable urban design principles need to be applied in all urban development. All these dimensions need to operate within two key processes involving vision-oriented and reformist thinking and a strong, community-oriented, democratic sustainability framework for decision-making.
\end{abstract}

Keywords: eco-city, sustainable city, transport, urban form, urban centres, urban design, green design, public realm, environmental technologies, economic innovation and creativity, sustainability processes

\section{Introduction}

Changing urban development from its present unsustainable forms and patterns is a very challenging process. Not only do urban form, transportation systems and water, waste and energy technologies have to change, but the value systems and underlying processes of urban governance and planning need to be reformed to reflect a sustainability agenda. Some would argue that we do not have much time left to make these changes before the ecological processes that underpin all of humanity's 
activities on earth become so severely threatened that it will pit nation against nation in order to access the remaining ecological services and resources that support life. ${ }^{1}$

The highly auto-dependent, resource consuming cities in North America and Australia account for a disproportionately high amount of the energy, materials and waste production of today's urban areas and require remedial actions of an unprecedented scale. Meanwhile, urbanisation proceeds at an alarming rate in newly industrialising cities, creating major problems on every level.

This paper sets out ten critical responses to the issue of changing the nature of urban development to a more ecological, sustainable model. These dimensions have at their core the issue of urban transport systems and their relationship to urban form and are therefore most focussed primarily on the problems of reducing automobile dependence in cities, building more sustainable urban form and creating more livable places. The paper is of particular relevance to cities in wealthier nations and those fast-growing prosperous cities in low and middle-income nations.

These ten dimensions are not exhaustive. For example, they do not deal with issues of poverty and inequality, neither do they cover politics and power or the many varied interests in urban decision-making processes. Nor are these ten transport, planning and design-oriented dimensions of sustainable city development exactly the same as other authors have described, but they do have significant overlaps ${ }^{2}$ and they draw heavily on my observations and comparative studies of cities in around the world over the last 26 years. Clearly, urban systems are very complex and cannot be reduced to any simple set of guidelines, but it is argued that not dealing with these ten dimensions will severely constrain any attempt by a prosperous or less prosperous city to become more sustainable.

The ten critical eco-city dimensions discussed here are:

(1) The city has a compact, mixed-use urban form that uses land efficiently and protects the natural environment, biodiversity and food producing areas.

(2) The natural environment permeates the city's spaces and embraces the city, while the city and its hinterland provide a major proportion of its food needs.

(3) Freeway and road infrastructure are de-emphasised in favour of transit, walking and cycling infrastructure, with a special emphasis on rail. Car and motorcycle use are minimised.

(4) There is extensive use of environmental technologies for water, energy and waste management - the city's life support systems become closed loop systems.

(5) The central city and sub-centres within the city are human centres that emphasise non-auto access and circulation and absorb a high proportion of employment and residential growth.

(6) The city has a high quality public realm throughout that expresses a public culture, community, equity and good governance. The public 
realm includes the entire transit system and all the environments associated with it.

(7) The physical structure and urban design of the city, especially its public environments are highly legible, permeable, robust, varied, rich, visually appropriate and personalised for human needs.

(8) The economic performance of the city and employment creation are maximised through innovation, creativity and the uniqueness of the local environment, culture and history, as well as the high environmental and social quality of the city's public environments.

(9) Planning for the future of the city is a visionary 'debate and decide' process, not a 'predict and provide', computer-driven process.

(10) All decision-making is sustainability-based integrating social, economic, environmental and cultural considerations, as well as compact, transit-oriented urban form principles. Such decision-making processes are democratic, inclusive, empowering and engendering of hope.

Some factors are discussed with reference to a set of international comparative urban data. ${ }^{3}$ The ten dimensions are drawn together into a simple conceptual model organised around four core Sustainable Urban Form and Transport dimensions, four Sustainable Technologies, Economics and Urban Design factors and two Overarching Processes for sustainable city development.

\section{Ten Key Dimensions for Sustainable City Development}

\section{(1) The city has a compact, mixed-use urban form, which uses land efficiently and protects the natural environment, biodiversity and food producing areas.}

How much land a city requires to house its people and accommodate its economic activities is critical in determining its sustainability, especially its transport patterns and impacts. The shape and form of a city sets the basic framework in which everything else about the city has to operate. These urban form factors are especially important in how the city relates to its bio-region, whether it consumes it for urban development or whether the urban area is able to draw much of its food, materials and water requirements from within its own boundaries or surroundings, thus minimising the city's ecological footprint.

Urban form as measured by urban density and centralisation of jobs, are found to have very strong relationships with transport patterns, especially the level of car dependence and the effectiveness of public transport. ${ }^{4}$ For example, if we correlate urban density with private car use ${ }^{5}$, urban density explains $84 \%$ of the variance in car travel (Figure 1).

\section{FIGURE 1 ABOUT HERE}

The negative consequences of low-density urban development are at the heart of many serious critiques of automobile cities and the environmental impacts of cities ${ }^{6}$. The strong relationship revealed by many studies between more compact, mixed use urban 
form and reduced car use is reflected in efforts around the world to reduce urban sprawl and create more transit-oriented communities ${ }^{7}$. These efforts to achieve more compact, people-scale, walkable development patterns are also associated with a need to build more effective community in cities and to create a much higher quality urban public realm that has a real sense of place and meaning for people ${ }^{8}$. Joel Kotkin states $^{9}$ :

The next great frontier is going to be the urbanization of suburbia. We will see the development of more urban villages...Land pressures, environmental pressures, NIMBY-ism, and people's exhaustion with the commute will lead to the creation of denser, more self-contained environments...the way we're going to contain sprawl will be by creating these village-like environments in suburbia, both in the older suburbs and further out.

Data on the urban form of cities worldwide are contained in Table $1^{1}$. European cities average 50 to 55 persons per ha, auto cities 15 to 26 persons per ha, while Asian cities average 150 persons per ha. In centralisation of jobs, European and Asian cities still have around $20 \%$ of jobs in their CBDs, US cities average less than $10 \%$ and Canadian and Australia/New Zealand cities are in between with 15\%. Both higher densities and higher centralisation are supportive of a greater role for public transport. More centralised cities tend to have less central city parking, stronger rail systems and more use of public transport for radial trips ${ }^{10}$. Higher density is also associated with greater mixing of land uses and shorter travel distances, so dense cities also tend to have higher use of non-motorised transport (dimension 3).

\section{TABLE 1 ABOUT HERE}

Overall, the positive effects on urban transport patterns of higher density and more centralised land use are clear and are further elaborated in subsequent sections. Higher densities can bring greater protection of the natural environment and food growing areas in around cities. Many European and Asian cities still embrace considerable local food production in farms and gardens within the city and its hinterlands ${ }^{11}$. This is only possible where the demands of urban sprawl do not devour most developable land.

\section{(2) The natural environment permeates the city's spaces and embraces the city, while the city and its hinterland provide a major proportion of its food needs.}

A city that is striving for a more ecological model will inevitably be concerned about access to green space and food security. The city for many people will remain an object of ambivalence unless it can be seen that cities can be genuinely 'green'. The potential for 'green living' in the city revolves significantly around different views about the merits of low versus high density living and the best way of 'restoring

\footnotetext{
${ }^{1}$ The data summarised by region in Table 1 and subsequent tables refer to a total of 84 cities worldwide in developed and developing countries. The abbreviations are as follows: CHN Chinese cities; LIA - Low Income Asian cities; LAM - Latin American cities; AFR African cities; MEA - Middle Eastern cities; EEU - Eastern European cities; WEU - Western European cities; HIA - High Income Asian cities; ANZ - Australia/New Zealand cities; USA - American cities; CAN - Canadian cities.
} 
the commons'. This is discussed in terms of a 'rural commons' view which has its origins in strong anti-urban sentiments which dislike 'density', and an 'urban commons' view which is pro-urban and values the city ${ }^{12}$. Both views are striving for sustainable settlements based on respect for 'the commons' - land held in common trust for the use and benefit of all. 'The commons' in reality extends to the air, the water and the natural landscapes that permeate our cities and natural areas.

The first view suggests that growing one's own food, practicing permaculture, recycling liquid and solid wastes, using decentralised energy and water supplies and generally 'living green', is only possible in a low density rural or semi-rural context. The city is seen as needing to be broken down into smaller settlements that will bring rural qualities and values back to the city. However, this ignores the fact that cities by their nature are concentrations of people and diversity and spreading activities out will exacerbate many serious problems, particularly automobile dependence ${ }^{13}$.

The second view is less concerned with self-sufficiency as with the integrity of the urban system. It suggests that creating higher density development will mean less land devoted to sprawl and more land for open space, gardens, urban agriculture, forestry and horticulture. Greater emphasis on community spaces should also mean more opportunity for locally managed systems for waste, energy and water. The urban commons approach promotes a city that is 'greener' in its overall functioning through more use of green transport modes, traffic calming to promote greener, safer streets, less energy use and less environmental impact.

The two opposing views are seen as having a resolution. The city can become more compact and urban, which can provide more space for nature in the city. This will help prevent cities from devouring rural and bushland areas with sprawl and reduce automobile dependence. Rural areas can grow in population and diversity through a rural commons approach to development (eg permaculture villages). Repopulation of declining country areas can help to develop economic vitality and diversity and enhance their sustainability. The key seems to lie in recognising and respecting the inherent urban qualities of the city and the rural qualities of the country, and not trying to meld one into the other.

There are many examples of cities that have adopted the urban commons approach and have become greener cities such as Zurich, Stockholm, Helsinki, and Freiburg. ${ }^{14}$ Through compact planning they have provided for urban agriculture, forests, and community gardens, as well as excellent public transport systems and high levels of walking and cycling. Environmental technologies such as renewable energy and localised management of water are also helping to "green" these cities. 


\section{(3) Freeway and road infrastructure is de-emphasised in favour of transit, walking and cycling infrastructure, with a special emphasis on rail. Car and motorcycle use are minimised.}

Private transport patterns

Table 2 reveals vast differences in private transport infrastructure and use in different cities. In 1995 car usage was lowest in the Chinese cities, representing just $4 \%$ of the level found in US cities.

\section{TABLE 2 ABOUT HERE}

In the Chinese and Low Income Asian clusters, motorcycles accounted for a sizeable quarter of total private motorised passenger kilometres. There is some evidence that motorcycles have flourished in high density, congested urban areas where segregated public transport systems are weak or absent. Motorcycles can avoid traffic queues and are the cheapest form of motorised private transport for moderate income people, but they are also a major cause of air pollution, noise, and transport deaths in these cities 15

Automobile use is linked closely to the provision of roads and parking. The most auto-dependent US cities had the highest freeway per person in the world, followed by the Australia/New Zealand and Canadian cities. Outside of these regions freeway and parking provision falls away rapidly, as does car use. Since as early as 1974, higher freeway provision has been linked with higher car and energy use in cities ${ }^{16}$. The mechanism for this has been explained in terms of longer travel distances rather than savings in time ${ }^{17}$.

Overall modal split patterns

Walking and cycling are the most sustainable modes. Chinese cities had the highest use of non-motorised modes (65\%). The other classes of cities were the automobile dependent, wealthy cities (Australia/New Zealand, Canada, and the USA) with low walking and cycling, the wealthy cities with strong public transport and nonmotorised mode use (Western Europe, High Income Asia), and the low income cities where public transport and non-motorised modes maintain large shares, serving huge urban poor populations, while the wealthy use private motor vehicles (Low Income Asia, Latin America, Africa, Middle East, Eastern Europe). Continued usage of walking and cycling in poorer cities is threatened by increasing motorisation and is a major problem for these cities in achieving more sustainable transport systems ${ }^{18}$.

\section{Public transport supply patterns}

Table 3 shows that public transport supply was lowest in Chinese, Middle Eastern, and US cities. In 1995, Chinese cities still relied heavily on non-motorised modes, and had the lowest public transport service in the world, with the least rail. US cities have had a long history of decline in public transport, notwithstanding a recent renaissance $^{19}$. The Western and Eastern European cities, High Income Asian cities, Latin American and African cities provided the highest quantity of public transport service. However, European and High Income Asian cities offered 46\% to 62\% of public transport services by rail, which was arguably more competitive with automobiles due to high reliability and speed. 


\section{TABLE 3 ABOUT HERE}

Public transport usage patterns

Table 4 shows US cities had the lowest rate of boardings per capita on public transport, while the Eastern European cities had the highest (12 times more). This was also reflected in modal split where US urban residents had 3\% of total daily trips on transit, compared to 47\% in Eastern European (Table 2). The other high users of public transport, either in terms of boardings per capita or modal share (but not always both) were High and Low Income Asian cities, Western European cities, Latin American, African and Chinese cities. For example, Chinese cities, despite poor transit service, had high per capita transit usage (375 boardings per capita), but the share of total trips was low (19\%).

\section{TABLE 4 ABOUT HERE}

Importance of rail and comparative modal speeds

The data highlight the integral role of urban rail systems in achieving high public transport ridership. Only the Western and Eastern European and High Income Asian cities had public transport systems that captured a large share of the overall transport market and these were the cities where urban rail systems were strongest. Table 5 shows that the ratio of segregated transit infrastructure to urban freeways in these high-income cities ranged from 3 to 9 , while in their more automobile dependent counterparts the ratio ranged from 0.4 to 2 . As noted, a lack of segregated public transport infrastructure is linked to high use of motorcycles, which compete for passengers with bus systems that are engulfed in traffic ${ }^{20}$.

\section{TABLE 5 ABOUT HERE}

The highest average bus speed in any cluster was $26 \mathrm{~km} / \mathrm{h}$ and across the 11 groups it was only $19 \mathrm{~km} / \mathrm{h}$. Chinese urban buses operated at about the same speed as bikes. Metro systems operated between 30 and $37 \mathrm{~km} / \mathrm{h}$ (average $34 \mathrm{~km} / \mathrm{h}$ ), while suburban rail systems averaged $43 \mathrm{~km} / \mathrm{h}$, compared to road traffic speed of only $34 \mathrm{~km} / \mathrm{h}$. Only rail systems compete with cars in speed, which is in turn linked to the provision of reserved alignments. This relative speed between public transport and private transport has been shown to be critical in cities. ${ }^{21}$

Without a commitment to better quality public transport systems, especially rail, and better conditions for pedestrians and cyclists, it is difficult for any city to become more sustainable.

\section{(4) There is extensive use of environmental technologies for water, energy and waste management - the city's life support systems become closed loop systems.}

Cities are consumers of natural capital such as water, energy and other resources and producers of large quantities of wastes, which must be absorbed by the natural systems upon which cities depend. There is now a well-documented view that cities are 'parasitic organisms'. It has been shown that the ecological footprint of prosperous cities already extends multiple-times beyond the areas of land that they actually occupy, while innumerable other less resource consuming, though fast growing cities in lower income nations, are increasing their impacts at an alarming 
rate $^{22}$. Indeed, there is now a global movement which argues that, given the profligate resource consumption and waste in wealthy nations and the pace of urbanisation, especially in developing countries, cities must become more sustainable ecosystems in their own right ${ }^{23}$, in order to avoid serious ecological collapses during this, the "century of cities"24. Still others have suggested that "... social, economic and cultural systems cannot escape the rules of abiotic and biotic nature." 25

If cities are to become sustainable, they must reduce their use of all resources and decrease their waste outputs. At the same time they must increase their livability in terms of health, employment, income, education, housing, leisure activities, accessibility, urban design quality and sense of community and neighbourhood. This argument has been systematised in terms of an 'extended metabolism' model of human settlements ${ }^{26}$.

One response to the above issues is deployment of localised or regional scale, decentralised environmental technologies, as opposed to large-scale, highly centralised systems that are managed by government authorities or, increasingly, corporatised entities with a public charter given by government. Renewable energy can be supplied through solar hot water technologies and photovoltaics, wind energy systems and methane etc. Buildings can maximise passive solar design thus minimising heating and cooling needs. For transport it is very difficult to find viable, alternatives to oil in sufficient quantities to meet current and future demands ${ }^{27}$. Electrically powered vehicles using renewable energy sources are probably the most promising to date.

Water can be harvested and stored at a local level to provide a significant proportion of drinking and other needs. Stormwater can be managed on-site through drainage swales and retention ponds that can also form water features within an urban development. Sewage can be treated using local biological treatment systems ${ }^{28}$. There are good examples of such local sewerage treatment systems on a district scale such as in Kolding, Denmark ${ }^{29}$.

The overall aims of environmental technologies are to maximise the possibility that cities can meet their needs from the natural capital of their own bioregions in a renewable way and to move to closed loop infrastructure systems that recycle and reuse their own wastes, so that the absorptive capacities of natural systems are not overwhelmed with the waste loads from urban areas.

A recent global competition has drawn attention to the above issues by asking a range of cities to develop a realisable 100-year staged vision for transforming their city into an ecological system (Vologda, San Diego/Tijuana, Changshu, Vancouver, Numazu, Mishima, Chuo City, Goa, Berlin, Buenos Aires). Virtually all the visions incorporate innovative systems for water, energy and waste adapted to their respective natural setting. All presented a vision where nature and natural processes are much more visible and accessible and all incorporated public transport, pedestrian and bicyclist systems to eliminate car dependence ${ }^{30}$. Indeed, virtually none of the visions would work without the city becoming non car-dependent. 
(5) The central city and sub-centres within the city are human centres that emphasise non-auto access and circulation and absorb a high proportion of employment and residential growth.

Amongst the most important parts of any city are its CBD and sub-centres. Central cities still remain the single biggest concentrations of jobs in most cities, despite the suburbanisation of work and the falling percentage of people employed in them ${ }^{31}$. The high and generally increasing number of jobs and floor-space mean that the central city still significantly shapes transport patterns. Public transport systems, especially rail, are focussed on central cities and congestion on radial routes is widespread.

The high profile status of the central city and intense traffic pressure mean that this area is almost always the focal point for new rail systems and the first to adopt sustainable transport and planning policies such as pedestrianisation, urban design and streetscape improvements, traffic calming schemes, control over parking provision, road pricing schemes to reduce traffic and residential revitalisation; eg Portland (Oregon), Singapore, Toronto, Freiburg, Copenhagen and many other European cities $^{32}$. Toronto, for example, experienced huge increases in central city housing and reduced commuting due to more workers walking, cycling and taking public transport $^{33}$. The size of the resident population of a central city appears to be inversely proportional to the amount of car parking it accommodates, since parking is an aggressive competitor for space ${ }^{34}$.

Many schemes to control the automobile in central cities (and sub-centres) have also aimed to improve economic performance. There is now considerable information showing that central cities with strong traffic restraint are better economically than those with generous parking ${ }^{35}$. It is also increasingly clear that attractive, human-scale centres with good public transport systems and diverse cultural and entertainment attractions are preferred sites for globally mobile jobs linked to the new information economy ${ }^{36}$. A further study states that "The new world will largely depend, as the old world did, on human creativity; and creativity flourishes where people come together face-to-face." ${ }^{37}$ (p.89)

A report of a global survey by Jones Lang LaSalle and LaSalle Investment Management summarised in the Bangkok Post, June 21, 2001 (Real Estate section) showed that "A global average of $77 \%$ of respondents felt proximity to good public transport was a critical factor in location decisions, particularly for firms in tight labour markets.”

It is extremely important in developing more sustainable cities to address these issues about the quality and accessibility of central cities and sub-centres.

(6) The city has a high quality public realm throughout that expresses a public culture, community, equity and good governance. The public realm includes the entire transit system and all the environments associated with it.

A compelling factor that distinguishes 'good' cities from 'bad' cities is how they address the public realm. ${ }^{38}$ Mike Davis writes about urban communities that have abandoned their sense of responsibility concerning 'the commons', the most obvious being shared urban spaces, streets, parks, transit systems and so on. ${ }^{39}$ He suggests Los 
Angeles has become a highly privatised, fear-driven environment which he characterises as "The Ecology of Fear" or "Fortress LA" in the following way:

A megalopolitan sprawl...economically and ecologically moribund, ravaged by social polarization and racial tensions that have provided fertile ground for: the criminalizing of non-whites, urban youth and the homeless;...the privatising of public space and; the proliferation of fortified suburban enclaves whose lawns bristle with warnings of 'armed response'... where public space and civil rights have been willingly relinquished by homeowners fearful of racial unrest and gang violence; and where upper and middle class citizenry has incarcerated itself in gated communities, or on family outings in surveilled, privately patrolled malls, "historic districts" or theme parks... (Davis interviewed in Dery, 95, Future Noir, 21-C, 3/95).

Robert Putnam addresses the breakdown (and rediscovery) of communalism in American society, at the core of which is the fragmentation and alienation that has occurred in American cities over the last 50 years under automobile-based planning policies $^{40}$.

Australian cities too suffer from similar, though perhaps not as extreme examples of retreat from the public realm and communal life. Social commentator Hugh Mackay laments thus ${ }^{41}$ :

If you've decided to be a two or three-car household, you've...increased the probability that you will continue to be a stranger to neighbours you never meet on the footpath. We may complain about the loss of a sense of belonging to a local community but, by our perfectly understandable enthusiasm for the car, we've taken such giant strides away from a communal life that we can hardly expect the community to re-emerge all by itself...The fear of urban violence...has already gripped many older people and many parents of young children...But many of us have already decided to create a climate of fear, which is conducive to violence, by teaching our children to avoid eye contact with strangers and by staying away from public spaces, such as streets and parks, which if only we thronged them would remain safe.

Discussions on eco-cities too easily focus on physical and biological systems, forgetting that cities have been created to enrich and progress humankind ${ }^{42}$. If we forget this we lose sight of the qualities needed to make great cities. In a wide-ranging article Barber discusses the problems and possibilities confronting Canadian cities ${ }^{43}$ :

A growing body of research is proving the effectiveness of civic engagement and its product social capital...no combination of traditional policies can ever in itself bring about good government and prosperity; that result depends entirely on the pre-existence of choral societies, sports clubs, interest groups and all other associations that stream like corpuscles through the urban body politic.”

In order to maximise the possibilities of social capital (and economic growth), cities must make their public realms humane, equitable places. Barber continues ${ }^{44}$ :

The quality of the natural and built environment is an increasingly important determinant of regional economic health [and] a healthy and socially stable workforce. In other words, governments must invest in the dignity of their cities...Nothing can be more democratic than investment in the public realm of a city. 
Alan Jacobs also espouses the great importance of a high quality urban public realm expressed through the vibrancy of streets. Great streets depend upon managing cars so that the needs of people and other modes are properly catered for ${ }^{45}$. Donald Appleyard demonstrated this with the greatest of clarity in his famous comparative study of streets in San Francisco with different levels of traffic and social interaction ${ }^{46}$.

(7) The physical structure and urban design of the city, especially its public environments are highly legible, permeable, robust, varied, rich, visually appropriate and personalised for human needs.

The physical layouts and designs that make the most enduring and loved cities have long been known. A range of authors provide detailed accounts of the design of Greek, Roman, Chinese, Japanese and new world cities such as Boston and Los Angeles, showing the central importance of, for example, permeable street patterns, based on regular or deformed grids and legible streetscapes punctuated by well-placed landmarks and significant buildings ${ }^{47}$. Others have developed a suite of measurable design qualities that need to be incorporated into urban development, as follows ${ }^{48}$ :

- Permeability - Places that are permeable provide access and a number of alternative routes through an area, a choice of how to get to places and have a clear definition between public and private places for routes to be identified and perceived as safe.

- Variety - Variety is concerned with the range of uses available to people. Places that have variety offer experiential choice, but only if they can be accessed, and they attract a variety of people at various times for varied reasons.

- Legibility - Legibility is about how easily people can understand a place. Legible places enable an understanding about how to negotiate an area and how quickly one can interpret what goes on there. Legibility can be achieved through street function, landmarks and different land uses.

- Robustness - Robustness is the flexibility to use a place for a variety of purposes, especially over a long period of time. Robustness is the means by which cities survive and are 'recycled' according to the needs of each era.

- Visual Appropriateness, Richness and Personalisation - These qualities are about the appearance and enjoyment of places. Places that display visual appropriateness and richness contain buildings that seem to 'fit' with the streetscape. They can be interpreted easily by many people and create satisfying sensory experiences. Visually appropriate places have uses that match their physical appearance. Personalisation is concerned with how comfortable and familiar a place is, and how well it engenders a sense of belonging.

It is difficult to create a city that truly meets human needs for interaction, support and community, or one that functions well in an economic sense, without embodying the above principles which reflect centuries of wisdom in place-making. Automobile 
cities, however, have largely ignored them, but are now rediscovering these principles through movements such as The New Urbanism ${ }^{49}$.

\section{(8) The economic performance of the city and employment creation are maximised through innovation, creativity and the uniqueness of the local environment, culture and history, as well as the high environmental and social quality of the city's public environments.}

Jane Jacobs shows that cities are the key sites and drivers of national economies and cities themselves cannot survive without a viable economic base ${ }^{50}$. Any city aspiring to sustainability cannot ignore its economic dimension. Since Jacobs' time, globalisation has strengthened the role of cities in driving the global economy. Indeed, there is now a global hierarchy or network of world cities which are tightly interconnected and dependent on each other for their sustainability.

For example, Egger states that ${ }^{51}$ :

through globalisation...cities more than ever before are becoming increasingly dependent upon other cities and regions in the world city network...The new economy consists of a global metanetwork of complex technological and human interactions.... city's sustainability is now far more dependent upon the world city network within which it exists than its previous raison d'être. (p. 1-2)

This world city network has heightened the competition between urban regions for global capital and jobs. Rather than employees going to where companies are locating, the new "creative class" of employees are to an extent dictating where companies locate according to the quality of life being offered by the city, demanding that cities be vibrant, livable and indeed walkable places offering a wide range of attractions. Richard Florida offers a detailed insight into what he calls "the rise of the creative class" and their impacts on cities ${ }^{52}$, although Florida's perspective has its critics, such as Joel Kotkin who claims that cities don't attract a middle-class, they create one. $^{53}$

Charles Landry describes how cities have to become creative to develop economic activities that help them compete for economic success, whilst at the same time respecting their local environments, skills and traditions. ${ }^{54}$ Landry's approach is based on discovering the uniqueness of a particular city in order to promote economic growth. Globalisation is thus a two-edged sword, linking up cities in ways that are unprecedented and causing a global homogenising effect on culture, but also driving cities to better distinguish themselves from each other.

In spite of some disagreements, there is little argument that part of the struggle today to develop a better urban economy is to create places that are environmentally and socially attractive, whereas it can be argued that cities which do not have the automobile under control run their environments down. In the 2003 Mercer worldwide quality of life survey (www.mercerHR.com), Zurich was ranked first and Geneva, Vancouver and Vienna, all cities with excellent public transport systems and very attractive public realms, shared equal second. Vancouver has no freeways and is an exemplar in the creation of convivial, vibrant and livable urban environments, as explained by Punter (2003). It has ranked one of the top three most livable cities in 
the world for the past 3 years. Interestingly, Atlanta, the highest car using and most sprawling major city in the USA and the world ${ }^{55}$, was deemed the least livable of all US cities in the 2004 survey, while the cities of San Francisco and Honolulu, which have good public transport systems by US standards and a range of high density, mixed use environments set within good public realms, ranked highest of the US cities. Whilst the quality of life ranking of these cities in this survey depends on many more dimensions than just transport, no highly automobile dependent cities ranked well, while all the most livable cities had at least respectable, if not very good public transport systems.

\section{(9) Planning for the future of the city is a visionary 'debate and decide' process, not a 'predict and provide', computer-driven process.}

\section{Predict and provide planning}

For any city aspiring to greater sustainability, the way it envisions its future and in particular the way it plans its future transport systems in relation to land use, will be critical. After WWII cities in the developed world became pre-occupied with planning for growth in automobiles. In 1954 Mitchell and Rapkin showed that traffic demand could be modelled based on the land uses in different areas. ${ }^{56}$ This, coupled with emerging computer technology, fostered the development of 'transportation/land use planning models' (4-step gravity models), which eventually became known as the Urban Transportation Planning (UTP) process. A new "scientific" and professional endeavour was born through the transport planning and traffic engineering disciplines. The basic philosophy of the UTP process was to plan for infrastructure supply to meet projected traffic growth - a "predict and provide" approach. This approach became characterised by self-fulfilling prophecies of spiralling traffic growth, congestion and road building. ${ }^{57}$

This method of transport planning has proven damaging to cities around the world. Freeways have been punched through neighbourhoods, demolishing large sections of urban fabric, severing communities and destroying natural environments and food producing areas. Roads have been built and widened to accommodate more traffic, reduce congestion, save fuel and reduce emissions, despite evidence that this approach fails. ${ }^{58}$ Public transport and particularly non-motorised modes have been big losers in a planning process optimised for the automobile. This is true in many newly industrialising cities today, such as in China and India, where non-motorised modes and public transport are declining rapidly. ${ }^{59}$

In particular, the UTP process did not recognise "induced traffic" whereby new road facilities generate completely new trips, which were never predicted, rather than freeing up the road system for the existing traffic. ${ }^{60}$ Research is also showing conclusively that just as new roads induce new traffic, removing road space can cause traffic to dissolve or disappear. ${ }^{61}$ It suggests that traffic does not behave like a 'liquid' and maintain a constant 'volume', but rather behaves more like a 'gas' that expands and contracts to fill the space provided for it. In many cities there is thus now a countervailing trend of transport demand management (TDM), which attempts to match demand for travel to the supply of infrastructure, rather than endlessly expanding supply to meet demand. ${ }^{62}$ Unfortunately, in lower income cities undergoing rapid motorisation, 'predict and provide' is still common. 
Debate and decide planning

Congestion relief and ever expanding mobility, rather than accessibility, have been pillars of the UTP process for many years. There is now, however, an awareness that the road building treadmill created by over-reliance on computer model predictions of traffic growth needs to change. This awareness has manifested itself in some basic questions being asked in cities, in particular about the goals and modus operandi of transport planning.

- What kind of city do we want in the future?

- Can our urban environment sustain the predicted levels of future traffic?

- Would we not be benefited more by actually reducing traffic?

- Are there other options and how do we break out of trend-based planning?

- What are the land use options for the city which will curb automobile travel?

- Can we manage demand for private transport and optimise use of the existing road network by making strategic investments in public transport, walking and cycling?

- Can the process of the last 50 years be reversed by reducing not expanding road space?

No city will be able to aspire to greater sustainability unless it responds to the above issues. This will require engagement with communities as part of a process of envisioning the future for the city, rather than just 'predicting and providing' for more traffic. What is needed is a new 'debate and decide' process where models are used to help envision a more ecological, sustainable future for the city.

\section{(10) All decision-making is sustainability-based, integrating social, economic, environmental and cultural considerations, as well as compact, transit-oriented urban form principles. Such decision-making processes are democratic, inclusive, empowering and engendering of hope.}

Ray Bradbury states that ${ }^{63}$ :

[A]t its deepest level it can be argued that sustainable development is not a motherhood issue at all, it is a subversive issue...This is a debate about how we should understand difficult things...It is the Galilean dialogue of our times.” (p1).

It is not surprising then that for sustainable development to be implemented, quite radical departures from normal planning and decision-making processes in cities will be required. This is why there are many activities in cities around the world that are establishing visions of sustainable development and how these can be realised. The key defining characteristics of these efforts are their engagement with diverse 'communities' or 'stakeholders' that constitute any city today and their capacity to infuse a new sense of hope about urban futures. A handful of the better examples are summarised here. Newman and Jennings provide a detailed overview ${ }^{64}$.

USEPA Green Community Visioning

The USEPA provides a toolkit for "Green Community Visioning”

(http://www.epa.gov/greenkit) designed to bring together a comprehensive range of people in a community to envision where they would like to be in stages over 30 years. The steps in the process are: Where are we now?; Where are we going?; Where 
do we want to be?: How do we get there?; Let's go! Smart Growth principles that limit sprawl and automobile dependence and integrate social, economic and environmental goals into decision making, rather than just focussing on congestion relief, are central in such visioning processes. The process results in a vision statement towards which all can work.

\section{Portland, Oregon}

Portland is perhaps the most successful and well-known example in the USA of a city that has reshaped itself under a strong vision extending as far back as the 1970s. At this time it established an urban growth boundary to limit sprawl, decided to build a light rail system call Metropolitan Area Express (MAX), which opened its first line in 1986 and scrapped a freeway that would have destroyed 3000 homes. ${ }^{65}$ LRT stations are now the major focus for all new growth in the Portland region, with numerous attractive, compact, mixed use centres developing along an extended LRT system and new tram system in the inner city. Parks and green spaces have been created and property values have risen on the back of strong population growth and company location decisions. Portland now has a visioning process called Region 2040, a broadbased community representation process involving 44 stakeholders developing a vision and strategic goals for the region. At the heart of Portland's growing success over many years has been strong community engagement and empowerment through groups such as 1000 Friends of Oregon who have fought for a sustainability-based vision for their region, focussed on reducing automobile dependence and radically improving public transport options.

\section{Perth, Western Australia}

Perth, Western Australia engaged in a community visioning process in 2003 called "Dialogue With The City", which evolved out of a broader State Sustainability Strategy involving 42 areas of government, together with business and civil society. The human settlements part of this strategy emphasises innovative and efficient use of resources, less waste output, enhanced equity and livability and a greater sense of place in local communities.

Faced with a huge increase in urban sprawl and car dependence, the State government decided to involve the community on an unprecedented scale to develop a future vision for Perth for 2030. The process involved a community survey of over 1700 households and one-day forum involving 1000 participants. A critical part of the forum was a game that each group of 10 people played to plan for the expected increase in population. Each decision taken had a flow on effect, which was either positive or negative. People were thus forced to confront the dilemmas of urban planning, trading-off personal lifestyle preferences with systems effects, such as loss of bushland, traffic congestion and other implications. All results were recorded and a final report can be found at http://www.dpi.wa.gov.au/dialogue/finalproc.pdf. The next phase of the exercise is an action plan called "The Network City," which calls for around $60 \%$ of new dwelling construction within existing built up areas to reduce car dependence and sprawl. The process forced participants to consider the social, economic and environmental considerations wrapped up in all urban planning, i.e. to adopt sustainability-based thinking. 
Vancouver, British Columbia

A 100-year sustainability vision for the Vancouver region was developed by the cities PLUS team (Planning for Long-term $\underline{\text { Urban }}$ Sustainability) using collaborative planning and engagement over a very short period of time. It involved government, business, utilities, civil sector, the research community based in universities and regional, national and international networks. The resulting vision won the International Competition of Sustainable Urban Systems Design. ${ }^{66}$ John Punter further elaborates Vancouver's present achievements in the sustainable cities field involving extensive community consultation and integrated thinking and professional practice. ${ }^{67}$

\section{Lower income cities}

Numerous examples of the success of such sustainability-based decision making, leadership and engagement have emerged in cities in, for example, Asia and Latin America. The Kampung Improvement Programme, a community-based programme in some Indonesian cities such as Surabaya shows what can be done to simultaneously improve the social, economic and environmental conditions through changes in housing, transport and public environments in what would previously be classed as slums. ${ }^{68}$ Curitiba over many years has transformed itself into something of a 'model' ecological city through its innovative public transport system and many other integrated sustainability-based projects, which have engaged the community (eg recycling, business development for lower income people, food programmes, flood control and green space expansion projects). ${ }^{69}$ To this list can now be added activities in Bogota, Colombia for its excellent bus-based public transport system (especially the Transmilenio) and extensive improvements for pedestrians and cyclists. Through its broad-based, sustainability-oriented and socially inclusive projects in the transport field, Bogota is now a great source of inspiration and hope to many lower income cities worldwide.

\section{Conclusions}

The findings of this paper can be summarised in Figure 2, which conceptualises and organises the ten key dimensions into four critical 'Sustainable Urban Form and Transport' factors, four essential factors under the heading of 'Sustainable Technologies, Economics and Urban Design' and two 'Overarching Process' dimensions related to planning and decision-making for sustainable cities. This 'model' suggests that sustainable urban form and transport are at the core of developing an eco-city. These factors form the shell or framework in which everything else is embedded and must operate. Compact, mixed use urban form is critical along with ensuring that the city protects and enhances its green spaces, including natural areas and food producing areas. The city should be strongly centralised around well-defined higher density centres linked to the public transport system. These must be the focal points for population and employment growth. Priority must be given to the development of first class public transport systems, walking and cycling environments must be of exemplary quality and road capacity increases should be minimal in order to curb automobile dependence.

Within this framework there are four key things that need to occur. Environmental technologies, ideally closed loop systems, need to be applied. Economic growth needs to emphasise creativity and innovation and to contribute to, and feed off, the growing 
environmental, social and cultural amenities. The public realm throughout the city needs to be high quality, and sustainable urban design principles need to be applied. Finally, all these dimensions need to operate within two key processes that involve vision-oriented, reformist thinking (debate and decide) rather than extrapolation of existing trends (predict and provide) and a strong, community-oriented sustainability framework for decision-making.

This paper makes no claim to have addressed everything that is important within the intense complexity of urban systems, but it is suggested that ignoring these dimensions will thwart any efforts to develop sustainable eco-cities. 
Figures and Tables

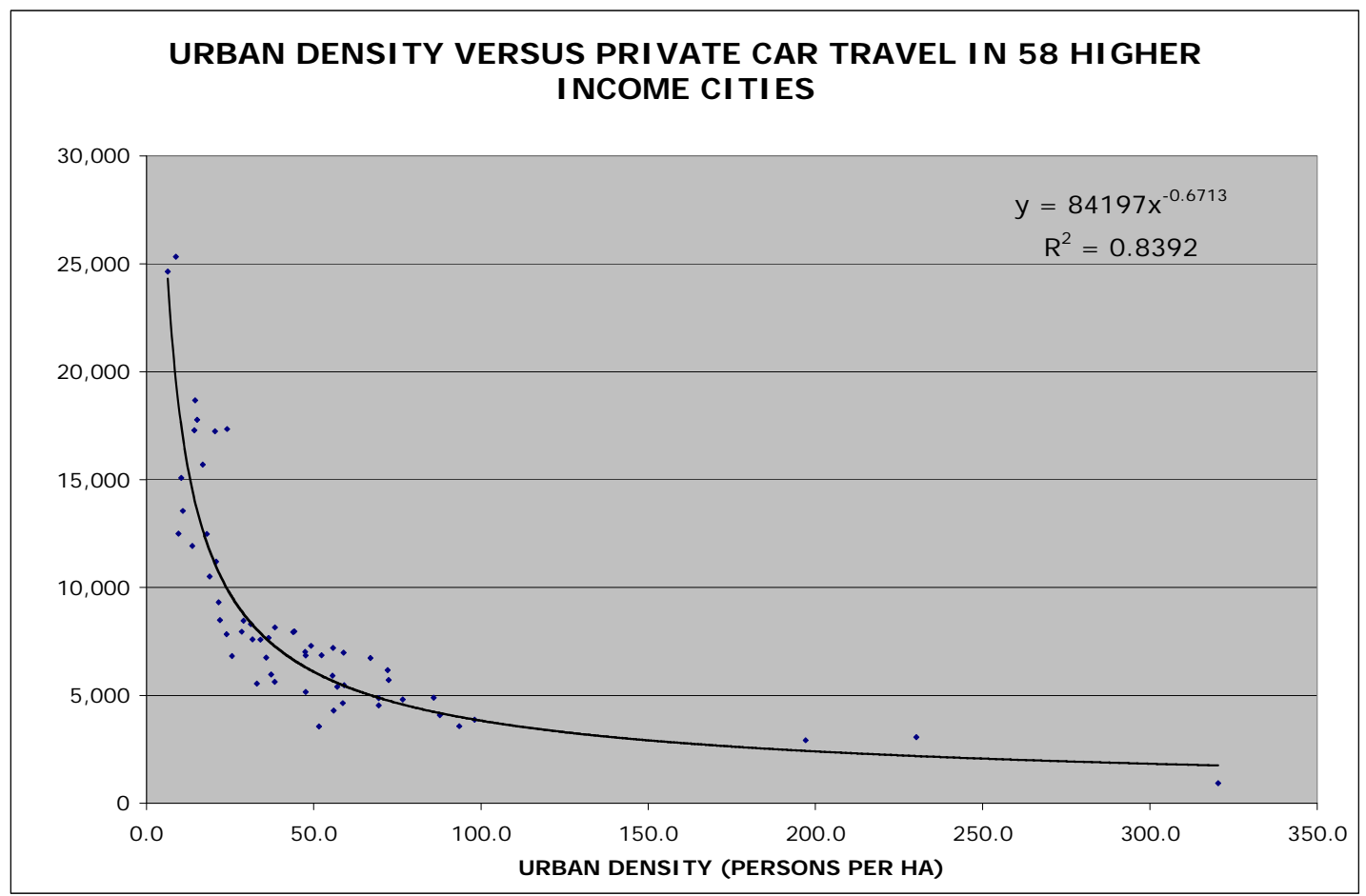

Figure 1. Urban density versus private car travel in 58 higher income cities (1995). 


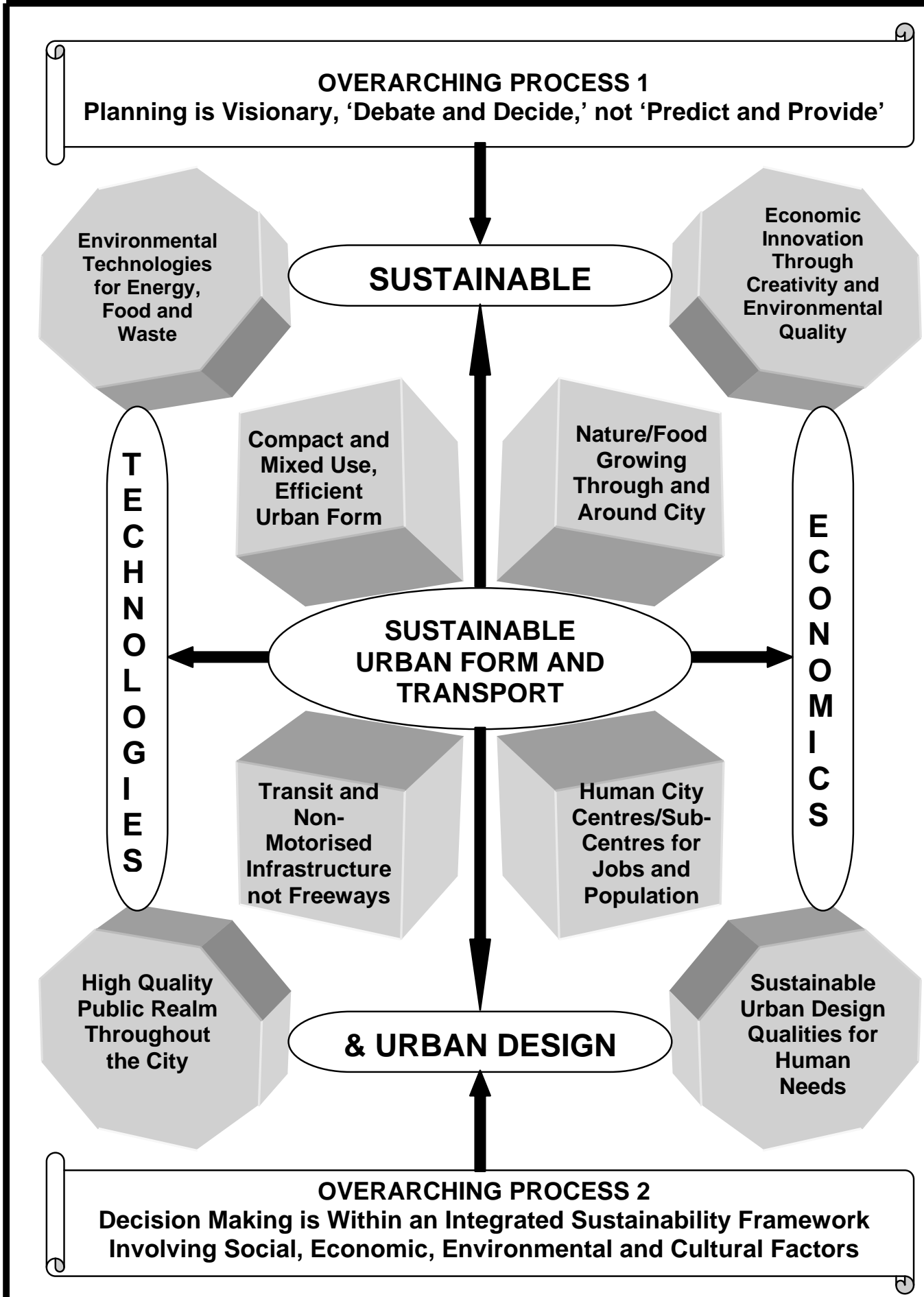

Figure 2. A conceptual model for eco-cities based on urban planning, urban transport and urban design considerations. 


\begin{tabular}{|c|c|c|c|c|c|c|c|c|c|c|c|}
\hline & CHN & LIA & LAM & AFR & MEA & EEU & WEU & HIA & ANZ & USA & CAN \\
\hline Urban density (persons /ha) & 146 & 204 & 75 & 60 & 119 & 53 & 55 & 150 & 15 & 15 & 26 \\
\hline Proportion of jobs in CBD (\%) & 51 & 17 & 29 & 15 & 13 & 20 & 19 & 19 & 15 & 9 & 16 \\
\hline
\end{tabular}

Table 1 Urban form in a global sample of cities, 1995

Source: Kenworthy and Laube (2001)

\begin{tabular}{|c|c|c|c|c|c|c|c|c|c|c|c|}
\hline Travel & CHN & LIA & LAM & AFR & MEA & EEU & WEU & HIA & ANZ & USA & CAN \\
\hline $\begin{array}{l}\text { Passenger car passenger } \\
\text { kilometres per capita } \\
\text { Motor cycle passenger }\end{array}$ & 814 & 1,855 & 2,862 & 2,652 & 3,262 & 2,907 & 6,202 & 3,614 & 11,387 & 18,155 & 8,645 \\
\hline kilometres per capita & 289 & 684 & 104 & 57 & 129 & 19 & 119 & 357 & 81 & 45 & 21 \\
\hline $\begin{array}{l}\text { Non motorised modes (\% } \\
\text { daily trips) }\end{array}$ & 65 & 32 & 31 & 42 & 27 & 26 & 31 & 28 & 16 & 8 & 10 \\
\hline $\begin{array}{l}\text { Length of freeway per person } \\
\text { (m/ } 1000 \text { persons) } \\
\text { Parking spaces per } 1000\end{array}$ & 3 & 15 & 3 & 18 & 53 & 31 & 82 & 20 & 129 & 156 & 122 \\
\hline CBD jobs & 17 & 127 & 90 & 252 & 532 & 75 & 261 & 105 & 505 & 555 & 390 \\
\hline
\end{tabular}

Table 2 Private mobility and private transport infrastructure in a global sample of cities, 1995 Source: Kenworthy and Laube (2001)

\begin{tabular}{|c|c|c|c|c|c|c|c|c|c|c|c|}
\hline & $\mathrm{CHN}$ & LIA & LAM & AFR & MEA & EEU & WEU & HIA & ANZ & USA & CAN \\
\hline $\begin{array}{l}\text { Overall average speed of public } \\
\text { transport }(\mathrm{km} / \mathrm{h})\end{array}$ & 14 & 18 & 18 & 31 & 21 & 21 & 26 & 30 & 33 & 27 & 25 \\
\hline * Average speed of buses $(\mathrm{km} / \mathrm{h})$ & 12 & 16 & 18 & 26 & 18 & 19 & 20 & 16 & 23 & 22 & 22 \\
\hline * Average speed of sub’n rail (km/h) & na & 33 & 41 & 34 & 37 & 38 & 49 & 47 & 45 & 55 & 49 \\
\hline Ratio of pub. vs priv. transport speeds & 0.73 & 0.81 & 0.60 & 0.80 & 0.68 & 0.71 & 0.79 & 1.04 & 0.75 & 0.58 & 0.57 \\
\hline
\end{tabular}

Table 3 Public transport supply and service in a global sample of cities, 1995 Source: Kenworthy and Laube (2001)

Note: na $=$ not applicable

\begin{tabular}{|c|c|c|c|c|c|c|c|c|c|c|c|}
\hline & CHN & LIA & LAM & AFR & MEA & EEU & WEU & HIA & ANZ & USA & CAN \\
\hline $\begin{array}{l}\text { Total public transport boardings per } \\
\text { capita }\end{array}$ & 375 & 231 & 265 & 195 & 152 & 711 & 297 & 430 & 84 & 59 & 140 \\
\hline $\begin{array}{l}\text { Rail boardings per capita (Tram, LRT, } \\
\text { Metro, Sub. rail) }\end{array}$ & 23 & 40 & 19 & 37 & 18 & 409 & 162 & 238 & 42 & 22 & 44 \\
\hline $\begin{array}{l}\text { Proportion of public transport } \\
\text { boardings on rail (\%) }\end{array}$ & 6 & 17 & 7 & 19 & 12 & 57 & 55 & 55 & 51 & 37 & 32 \\
\hline $\begin{array}{l}\text { Proportion of total motorised } \\
\text { passenger kilometres on public } \\
\text { transport (\%) }\end{array}$ & 55 & 41 & 48 & 51 & 29 & 53 & 19 & 46 & 7 & 3 & 10 \\
\hline
\end{tabular}

Table 4 Public transport mobility patterns in a global sample of cities, 1995

Source: Kenworthy and Laube (2001) 


\begin{tabular}{|c|c|c|c|c|c|c|c|c|c|c|c|}
\hline & CHN & LIA & LAM & AFR & MEA & EEU & WEU & HIA & ANZ & USA & CAN \\
\hline $\begin{array}{l}\text { Total length of reserved public } \\
\text { transport routes per } 1000 \text { persons } \\
\text { (m/1000 person) }\end{array}$ & 2 & 16 & 19 & 40 & 16 & 201 & 192 & 53 & 215 & 49 & 55 \\
\hline $\begin{array}{l}\text { Total length of reserved public } \\
\text { transport routes per urban hectare } \\
(\mathrm{m} / \mathrm{ha})\end{array}$ & 0.32 & 2.50 & 1.15 & 2.39 & 2.18 & 10.67 & 9.46 & 5.87 & 3.41 & 0.81 & 1.44 \\
\hline $\begin{array}{l}\text { Ratio of segregated transit } \\
\text { infrastructure versus expressways }\end{array}$ & 0.77 & 1.33 & 3.36 & 3.16 & 3.54 & 9.11 & 3.12 & 3.34 & 2.00 & 0.41 & 0.55 \\
\hline
\end{tabular}

Table 5 Public transport infrastructure in a global sample of cities, 1995

Source: Kenworthy and Laube (2001) 


\section{References}

${ }^{1}$ Woodbridge, R. (2004), The Next World War: Tribes, Cities, Nations and Ecological Decline, University of Toronto Press, Toronto. 328 pages.

${ }^{2}$ Beatley, T. (2000), Green Urbanism: Learning from European Cities, Island Press, Washington DC, 491 pages.

Register, R. (2003), Ecocities: Building Cities in Balance with Nature, Berkeley Hills Books, Berkeley, California. 290 pages.

Corbett, J and Corbett, M. (2000), Designing Sustainable Communities: Learning from Village Homes, Island Press, Washington DC, 235 pages.

${ }^{3}$ Kenworthy J, and Laube F. (2001), The Millennium Cities Database for Sustainable Transport, International Union of Public Transport (UITP), Brussels and Institute for Sustainability and Technology Policy (ISTP), Perth: CD ROM database.

${ }^{4}$ Thomson, J.M. (1977), Great Cities and Their Traffic, Penguin Books, Middlesex, England, 344 pages.

Newman, P.W.G. and Kenworthy, J.R. (1989), Cities and Automobile Dependence: An International Sourcebook, Gower, Aldershot, England, 388 pages.

Newman, P.W.G. and Kenworthy, J.R. (1999), Sustainability and Cities: Overcoming Automobile Dependence, Island Press, Washington DC, 442 pages.

Kenworthy, J. and Laube, F. (1999) (with Newman, P., Barter, P., Raad, T., Poboon, C., and Guia, B), An International Sourcebook of Automobile Dependence in Cities, 1960-1990, University Press of Colorado, Niwot, Colorado, USA, 704 pages.

Cervero, R. (1995), “Sustainable new towns: Stockholm’s rail served satellites”, Cities Vol 12, No 1, pages 41-51.

Cervero, R. (1998), The Transit Metropolis, Island Press, Washington DC, 464 pages. Holtzclaw, J. (1990), "Explaining urban density and transit impacts on auto use”, Report to Natural Resources Defense Council, Washington DC and The Sierra Club, San Francisco.

Holtzclaw, J. (1994), "Using residential patterns and transit to decrease auto dependence and costs”, Report to Natural Resources Defense Council, Washington DC.

Naess, P. (1993a), “Energy use for transport in 22 Nordic towns”, NIBR Report No 2, Norwegian Institute for Urban and Regional Research, Oslo.

Naess, P. (1993b), “Transportation energy in Swedish towns and regions”, Scandinavian Housing and Planning Research, Vol 10, pages 187-206.

${ }^{5}$ Kenworthy J, and Laube F. (2001), The Millennium Cities Database for Sustainable Transport, International Union of Public Transport (UITP), Brussels and Institute for Sustainability and Technology Policy (ISTP), Perth: CD ROM database.

${ }^{6}$ Bank of America (1994), "Beyond sprawl: New patterns of growth to fit the new California”, Bank of America, California Resources Agency, Greenbelt Alliance and Low Income Housing Fund, San Francisco, California.

Kunstler, J. H. (1993), The Geography of Nowhere, Touchstone, New York, 304 pages.

Gillham, O. (2002), The Limitless City: A Primer on the Urban Sprawl Debate, Island Press, Washington DC, 309 pages. 
Newman, P.W.G. and Kenworthy, J.R. (1999), Sustainability and Cities: Overcoming Automobile Dependence, Island Press, Washington DC, 442 pages.

${ }^{7}$ Calthorpe, P. (1993), The Next American Metropolis: Ecology and Urban form, Princeton Architectural Press, New Jersey, 175 pages.

Beimborn, E. and Rabinowitz, H. with Gugliotta, P., Mrotek, C. and Yan, S. (1991), Guidelines for transit sensitive suburban land use design, US Department of Transportation Report, DOT-T-91-13, Washington DC.

Bernick, M. and Cervero, R. (1997), Transit villages in the 21st century, McGraw Hill, New York, 387 pages.

Williams, K., Burton, E. and Jenks, M. (editors) (2000), Achieving Sustainable Urban Form, E and FN Spon, London, 388 pages.

${ }^{8}$ Langdon, P. (1994), A Better Place to Live: Reshaping the American Suburb, The University of Massachusetts Press, Amherst, 270 pages.

Moe, R. and Wilkie, C. (1997), Changing Places: Rebuilding Community in the Age of Sprawl, Henry Holt and Company, New York, 288 pages.

Calthorpe, P and Fulton, W. (2001), The Regional City: Planning for the End of Sprawl, Island Press, Washington DC, 304 pages.

Benfield, F.K., Terris, J. and Vorsanger, N. (2001), Solving Sprawl: Models of Smart Growth in Communities Across America, Island Press, Washington DC, 200 pages.

${ }^{9}$ Pedersen, M.C. (2004), "Cities in the Digital Age: City scholar Joel Kotkin argues against the idea of an urban revitalization panacea”, www.metropolismag.com/html/content_0104/ob/ob01_0104.html, accessed

September 26, 2004

${ }^{10}$ Thomson, J.M. (1977), Great Cities and Their Traffic, Penguin Books, Middlesex, England, pages.

${ }^{11}$ Beatley, T. (2000), Green Urbanism: Learning from European Cities, Island Press, Washington DC, 491 pages.

12 Newman, P. (1991), “Sustainable settlements: Restoring the commons”, Habitat, August, pages 18-21.

${ }^{13}$ Schneider, K.R. (1979), On the Nature of Cities: Toward Enduring and Creative Human Environments, Jossey-Bass Publishers, San Francisco, 352 pages.

${ }^{14}$ Beatley, T. (2000), Green Urbanism: Learning from European Cities, Island Press, Washington DC, 491 pages.

Newman, P.W.G. and Kenworthy, J.R. (1999), Sustainability and Cities: Overcoming Automobile Dependence, Island Press, Washington DC, 442 pages.

${ }^{15}$ Barter, P.A. (1998), An International Comparative Perspective on Urban Transport and Urban Form in Pacific Asia: Responses to the Challenge of Motorisation in Dense Cities, PhD Thesis, Murdoch University, Perth. 
Badami, M.G. (2005), “The urban transport challenge in India: Considerations, implications and strategies”, International Development Planning Review. Vol 27, No 2, pages 169-194.

${ }^{16}$ Watt, K.E.F. and Ayres, C. (1974), "Urban land use patterns and transportation energy cost", Presented to the Annual Meeting of the American Association for the Advancement of Science, San Francisco.

${ }^{17}$ Newman, P. W. G. and Kenworthy, J. R. (1984),” The use and abuse of driving cycle research: Clarifying the relationship between traffic congestion, energy and emissions”, Transportation Quarterly Vol 38, No 4, pages 615-635.

Newman, P. W. G. and Kenworthy, J. R. (1988), "The transport energy trade-off: Fuel-efficient traffic versus fuel-efficient cities”, Transportation Research Vol 22A, No 3, pages 163-174.

Newman, P.W.G. and Kenworthy, J.R. (1989), Cities and Automobile Dependence: An International Sourcebook, Gower, Aldershot, England, 388 pages.

${ }^{18}$ Kenworthy, J.R, and Hu, G. (2002), “Transport and urban form in Chinese cities: An international and comparative policy perspective with implications for sustainable urban transport in China”, DISP Vol 151, pages 4-14.

Kenworthy, J.R., and Townsend, C. (2002), “An international comparative perspective on motorisation in urban China: Problems and prospects”, IATSS Research Vol 26, No 2, pages 99-109.

Badami, M.G. (2005), "The urban transport challenge in India: Considerations, implications and strategies”, International Development Planning Review. Vol 27, No 2, pages 169-194.

${ }^{19}$ Pucher, J. (2002). "Renaissance of public Transport in the United States?”, Transportation Quarterly Vol 56, No 1, pages 33-49.

${ }^{20}$ Barter, P.A. (1998), An International Comparative Perspective on Urban Transport and Urban Form in Pacific Asia: Responses to the Challenge of Motorisation in Dense Cities, PhD Thesis, Murdoch University, Perth.

Badami, M.G. (2005), “The urban transport challenge in India: Considerations, implications and strategies”, International Development Planning Review. Vol 27, No 2, pages 169-194.

${ }^{21}$ Newman, P. and Kenworthy, J. (1999), “'Relative speed’ not 'time savings': A new indicator for sustainable transport”, Papers of the $23^{\text {rd }}$ Australasian Transport Research Forum, Perth Western Australia, 29 September - 1 October, Volume 23, Part 1: pages 425-440.

${ }^{22}$ Woodbridge, R. (2004), The Next World War: Tribes, Cities, Nations and Ecological Decline, University of Toronto Press, Toronto. 328 pages.

Wackernagel, M. and Rees, W. (1996), Our ecological footprint: Reducing human impact on the earth, New Society Publishers, Philadelphia, 176 pages.

${ }^{23}$ Newman, P. and Jennings, I. (2004), Cities as Sustainable Ecosystems, United Nations Environment Program, Osaka, 196 pages. 
${ }^{24}$ Woodbridge, R. (2004), The Next World War: Tribes, Cities, Nations and Ecological Decline, University of Toronto Press, Toronto. 328 pages.

${ }^{25}$ Tjallingii, S. P. (1991), “The responsible city”, International Federation for Housing and Planning. International Conference, Berlin, p.7.

${ }^{26}$ Newman, P.W.G. and Kenworthy, J.R. (1999), Sustainability and Cities: Overcoming Automobile Dependence, Island Press, Washington DC, 442 pages, (pp 7-14).

${ }^{27}$ Fleay, B. J. (1995), The Decline of The Age of Oil, Pluto Press, Sydney, 152 pages.

${ }^{28}$ Niemczynowicz, J. (1992), "Water management and urban development: A call for realistic alternatives for the future”, Impact of Science on Society Vol 42, No 2, pages 131147.

Niemczynowicz, J. (1993), "New aspects of sewerage and water technology”, Ambio Vol 22, No 7, pages 449-455.

${ }^{29}$ Newman, P.W.G. and Kenworthy, J.R. (1999), Sustainability and Cities:

Overcoming Automobile Dependence, Island Press, Washington DC, 442 pages.

${ }^{30}$ Itoh, S. (editor) (2003) Proposals for the International Competition of Sustainable Urban Systems Design: Report of the International Gas Union Special Project, The Institute of Behavioural Sciences, Tokyo. 311 pages.

${ }^{31}$ Kenworthy J, and Laube F. (2001), The Millennium Cities Database for Sustainable Transport, International Union of Public Transport (UITP), Brussels and Institute for Sustainability and Technology Policy (ISTP), Perth: CD ROM database.

Kenworthy, J. and Laube, F. (1999) (with Newman, P., Barter, P., Raad, T., Poboon, C., and Guia, B), An International Sourcebook of Automobile Dependence in Cities, 1960-1990, University Press of Colorado, Niwot, Colorado, USA, 704 pages.

${ }^{32}$ Monheim, R. (1988), "Pedestrian zones in West Germany - The dynamic development of an effective instrument to enliven the city centre”, In Hass-Klau, C. (editor), New Life for City Centres: Planning Transport and Conservation in British and German Cities, Anglo-German Foundation, London, pages 107-130.

Gehl, J. and Gemzøe, L. (1996), Public Spaces, Public Life, The Danish Architectural Press and the Royal Danish Academy of Fine Arts School of Architecture Publishers, Copenhagen, 96 pages.

Jacobs, J. (1961), The Death and Life of Great American Cities, Vintage Press, New York, 474 pages.

${ }^{33}$ Nowlan, D. M. and Stewart, G. (1992), "The effect of downtown population growth on commuting trips: some recent Toronto experience", Journal of The American Planning Association Vol 57, No 2, pages 165-182.

${ }^{34}$ Newman, P.W.G. and Kenworthy, J.R. (1988), "Parking and city centre vitality: An international assessment”, Proceedings of the First International Parking Convention, Perth, WA, October, pages 320-333. 
${ }^{35}$ TEST (1989), Quality Streets: How Traditional Urban Centres Benefit from Traffic Calming, Transport and Environment Studies, London, 252 pages.

Hass-Klau, C. (1993), "Impact of pedestrianization and traffic calming on retailing: A review of the evidence from Germany and the UK”, Transport Policy Vol 1, No 1, pages 2131.

${ }^{36}$ Newman, P.W.G., Kenworthy, J.R. and Laube, F. (1999), “The Global City and Sustainability - Perspectives from Australian Cities and a Survey of 37 Global Cities”, in Brotchie, J., P. Newton, P. Hall and J. Dickey (editors), East-West Perspectives of $21^{\text {st }}$ Century Urban Development: Sustainable Eastern and Western Cities in the New Millennium, Ashgate, Aldershot, England, pages 327354.

${ }^{37}$ Hall, P. (1997), "Reflections past and future on planning cities", Australian Planner, Vol 34, No 2, pages 83-89.

${ }^{38}$ Newman, P. (1990), “The search for the good city”, Town and Country Planning Vol 59, No 10, pages 272-275.

${ }^{39}$ Davis, M. (1990), City of Quartz: Excavating the Future in Los Angeles, Vintage, London, 462 pages.

${ }^{40}$ Putnam, R. (2001), Bowling Alone: The Collapse and Revival of American Community, Simon and Schuster, New York, 544 pages.

${ }^{41}$ Mackay, H. (1994), “The future stops here”, The Weekend Australian, The Weekend Review, September 3-4, page16.

${ }^{42}$ Mumford, L. (1961), The City in History. Penguin, Harmondsworth, England, 696 pages.

${ }^{43}$ Barber, J. (1995), “Mending Our Lovely Metros”, The Globe and Mail, Focus Section D, September 9, 1995.

${ }^{44}$ Barber, J. (1995), “Mending Our Lovely Metros”, The Globe and Mail, Focus Section D, September 9, 1995.

45 Jacobs, A. B. (1993), Great Streets, The MIT Press, Massachusetts, 344 pages.

${ }^{46}$ Appleyard, D. (1981), Livable Streets, University of California Press, Berkeley, 382 pages.

${ }^{47}$ Lynch, K. (1960), The Image of The City, The MIT Press, Cambridge, Massachusetts, 194 pages.

Lynch, K. (1981), Good City Form, The MIT Press, Cambridge, Massachusetts, 514 pages.

Kostoff, S. (1991), The City Shaped: Urban Patterns and Meanings Through History, Thames and Hudson, London, 352 pages. 
Bacon, E.N. (1974), Design of Cities, Penguin Books, New York, 336 pages.

${ }^{48}$ Bentley, I., Alcock, A., Murrain, P., McGlynn, S. and Smith, G, (1985), Responsive Environments: A Manual for Designers, Architectural Press, Oxford, 152 pages.

${ }^{49}$ Katz, P. (1994), The New Urbanism: Toward an Architecture of Community, McGraw Hill, New York, 288 pages.

50 Jacobs, J. (1969), The Economy of Cities, Random House, New York, 288 pages. Jacobs, J. (1984), Cities and The Wealth of Nations, Penguin, Harmondsworth, 257 pages.

${ }^{51}$ Egger, S. (2003), “Globalisation and the sustainability of cities: A Methodology for determining their relationship”, Presented to MODSIM 2003, Townsville, Australia.

${ }^{52}$ Florida, R. (2002), The Rise of The Creative Class: And How It's Transforming Work, Leisure, Community and Everyday Life, Perseus Books Group, New York, 416 pages.

Florida, R. (2004), Cities and The Creative Class, Routledge, New York. 208 pages.

${ }^{53}$ Pedersen, M.C. (2004), “Cities in the Digital Age: City scholar Joel Kotkin argues against the idea of an urban revitalization panacea",

www.metropolismag.com/html/content_0104/ob/ob01_0104.html, accessed

September 26, 2004

${ }^{54}$ Landry, C. (2000), The Creative City: A Toolkit for Urban Innovators, Earthscan Publications, London, 300 pages.

${ }^{55}$ Kenworthy J, and Laube F. (2001), The Millennium Cities Database for Sustainable Transport, International Union of Public Transport (UITP), Brussels and Institute for Sustainability and Technology Policy (ISTP), Perth: CD ROM database.

${ }^{56}$ Mitchell, R.B. and Rapkin, C. (1954), Urban Traffic: A Function of Land Use, Columbia University Press, New York, 226 pages.

${ }^{57}$ Kenworthy, J.R. (1990), “Don't shoot me I'm only the transport planner (apologies to Elton John)”, in Newman, P., J. Kenworthy, and T. Lyons, (editors), Transport Energy Conservation Policies for Australian Cities: Strategies for Reducing Automobile Dependence, Murdoch University, Perth, Chapter 16.

${ }^{58}$ Newman, P. W. G. and Kenworthy, J. R. (1984),” The use and abuse of driving cycle research: Clarifying the relationship between traffic congestion, energy and emissions”, Transportation Quarterly Vol 38, No 4, pages 615-635.

Newman, P. W. G. and Kenworthy, J. R. (1988), “The transport energy trade-off: Fuel-efficient traffic versus fuel-efficient cities”, Transportation Research Vol 22A, No 3, pages 163-174.

${ }^{59}$ Kenworthy, J.R, and Hu, G. (2002), “Transport and urban form in Chinese cities: An international and comparative policy perspective with implications for sustainable urban transport in China”, DISP Vol 151, pages 4-14. 
Kenworthy, J.R., and Townsend, C. (2002), “An international comparative perspective on motorisation in urban China: Problems and prospects”, IATSS Research Vol 26, No 2, pages 99-109.

Badami, M.G. (2005), “The urban transport challenge in India: Considerations, implications and strategies”, International Development Planning Review. Vol 27, No 2, pages 169-194.

${ }^{60}$ Goodwin, P. B. (1997), "Solving congestion (when we must not build roads, increase spending, lose votes, damage the economy or harm the environment, and will never find equilibrium)”, Inaugural Lecture for the Professorship of Transport Policy, University College, London, 23 October.

Samuels, T. (1994), "Traffic expands to fill the available road space: Understanding North America's traffic congestion crisis”, The Better Transportation Coalition, Toronto, Ontario, November.

${ }^{61}$ Surface Transportation Policy Project (1998) March issue of Progress Vol VIII, No 2). Three short articles by Hank Dittmar, Donald D.T. Chen and Jill Kruse.

${ }^{62}$ Goodwin, P. B. (1997), "Solving congestion (when we must not build roads, increase spending, lose votes, damage the economy or harm the environment, and will never find equilibrium)”, Inaugural Lecture for the Professorship of Transport Policy, University College, London, 23 October.

${ }^{63}$ Bradbury, R.H. (1998), "Sustainable development as a subversive issue”, Nature and Resources Vol 34, No 4), (www.tjurunga.com/thinking/papers/sustain.html).

${ }^{64}$ Newman, P. and Jennings, I. (2004), Cities as Sustainable Ecosystems, United Nations Environment Program, Osaka, 196 pages.

${ }^{65}$ Newman, P.W.G. and Kenworthy, J.R. (1999), Sustainability and Cities:

Overcoming Automobile Dependence, Island Press, Washington DC, 442 pages, (pp 226-230).

${ }^{66}$ Itoh, S. (editor) (2003) Proposals for the International Competition of Sustainable Urban Systems Design: Report of the International Gas Union Special Project, The Institute of Behavioural Sciences, Tokyo. 311 pages.

${ }^{67}$ Punter, J. (2003), The Vancouver Achievement: Urban Planning and Design, UBC Press, Vancouver, 447 pages.

${ }^{68}$ Silas, J. (1993), Surabaya: 1293-1993: A City of Partnership. Municipal Government of Surabaya, Surabaya, Indonesia.

${ }^{69}$ Newman, P.W.G. and Kenworthy, J.R. (1999), Sustainability and Cities: Overcoming Automobile Dependence, Island Press, Washington DC, 442 pages, (pp198-200). 